\title{
Assessment of Knowledge and Practices of Parents Regarding Home Management of Children with Nephrotic Syndrome at Selected Hospitals of Haryana, India
}

\author{
Sarika* \\ Maharishi Markandeshwar College of Nursing-Mullana, Ambala, Haryana, India \\ *Corresponding author
}

\begin{tabular}{|c|c|}
\hline \multicolumn{2}{|r|}{ A B S T R A C T } \\
\hline & \multirow{5}{*}{ 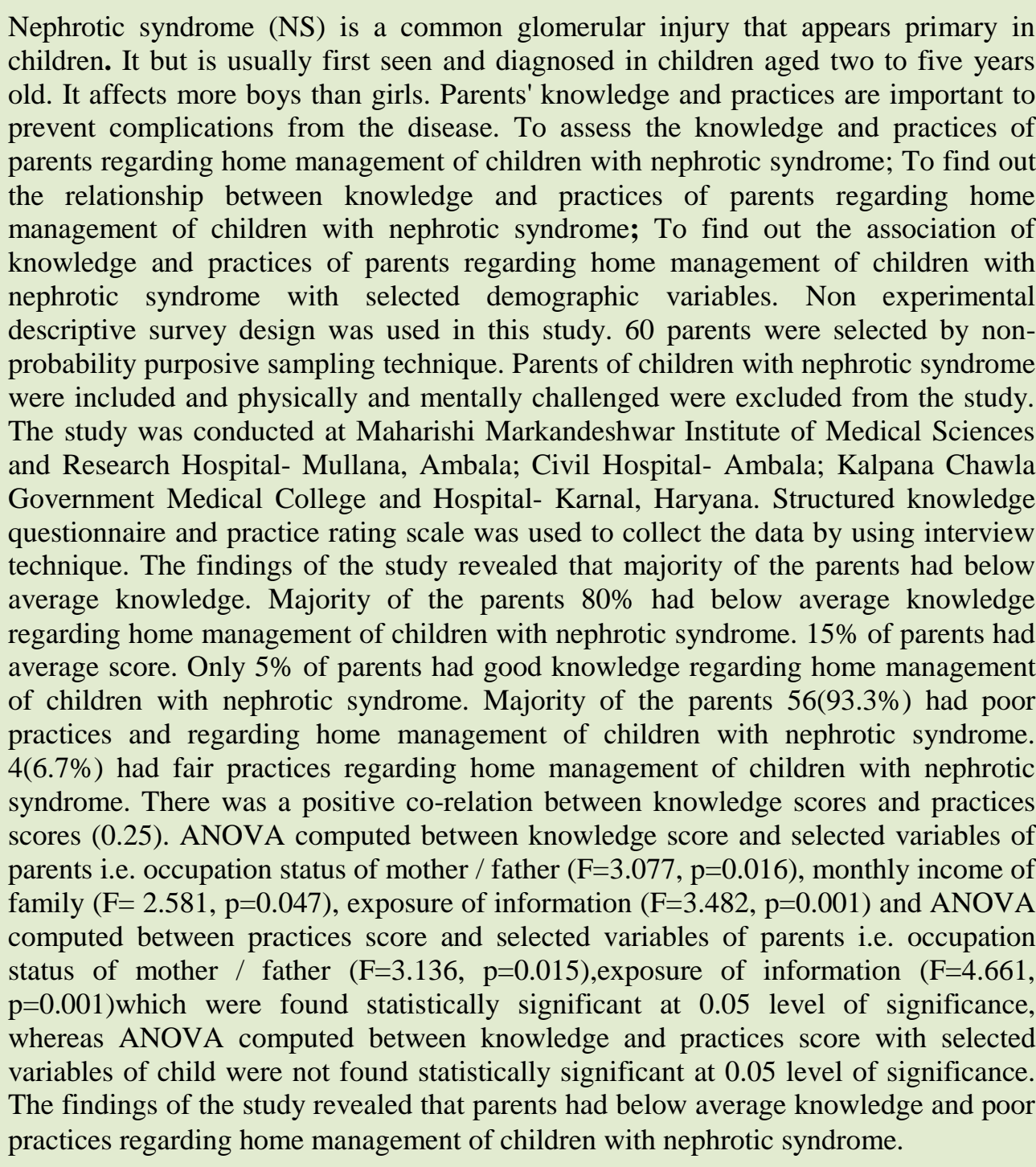 } \\
\hline & \\
\hline Article Info & \\
\hline & \\
\hline & \\
\hline
\end{tabular}




\section{Introduction}

\section{Background of the study}

Healthy children become healthy adults, people who create better lives for themselves, their communities and their countries. Improving the health of children is one responsibility among many in the fight against poverty. The Children of today are the resources of the future. Preservation of their lives will always be a priority. Child health includes the care of the children from infancy to adolescence(1).

Nephrotic Syndrome is a group of signs and such as glomerulonephritis symptoms including low blood protein, proteinuria and hyperlipidemia. The most common symptoms of idiopathic nephrotic syndrome include edema, generalized edema. Nephrotic Syndrome is a primarily pediatric disorder which initially noted around the eyes and in the lower extremities and with the time the edema becomes generalized. Nephrotic Syndrome is 15 times more common in children than adults and affects 16 in 100,000 children worldwide/year, making this with the development of ascites, pleural effusion, condition one of the common childhood kidney diseases genital edema, weight gain, oliguria, anorexia, irritability and the ratio of males to females is approximately $2: 1$.

The incidence of idiopathic Nephrotic syndrome in the United States has been reported to be 2.7 new cases per 100,000 children per year, and the cumulative prevalence rate is 16 per 100,000 children. The ratio of males to females is approximately 2:1 during childhood, but the sex difference wanes by adolescence. There is an increased familial incidence, particularly among siblings. The infection of the genitourinary system commonly seen in children is Nephrotic syndrome. It is one of the several manifestations of glomerulonephritis. Nephrotic syndrome in children differs from that of adults in several aspects like etiology clinical manifestations, prognosis and outcome, hence require a special consideration(3).

\section{Need of the study}

Parents should be educated to pay attention to child's health, but do not overprotect the child. Child needs to continue his or her usual activities, such as attending school and seeing friends. Parents should continue to treat this child like all other children in the family. Home monitoring of urine protein and fluid status is an important aspect of management. All patients and parents should be trained to monitor first morning urine proteins at home with urine dipstick. Urine testing at home is also useful in monitoring response (or nonresponse) to steroid treatment. Accordingly, understanding and improving parental knowledge, practices regarding home management of children with nephrotic syndrome are essential. Many studies have investigated the etiology and natural history of nephrotic syndrome and evaluated various management strategies, but very less information is available about parental knowledge, and practices regarding home management of children with nephrotic syndrome. However, further studies are required for the application of questionnaires among different cultures(1).

\section{Objectives}

To assess the knowledge and practices of parents regarding home management of children with nephrotic syndrome.

To find out the relationship between knowledge and practices of parents regarding home management of children with nephrotic syndrome. 
To find out the association of knowledge and practices of parents regarding home management of children with nephrotic syndrome.

\section{Materials and Methods}

An exploratory descriptive study was conducted on 60 parents whose child having nephrotic syndrome was selected by using non probability purposive sampling technique. Parents of children aged 1-15 years diagnosed with nephrotic syndrome were selected from MMIMS\&R Hospital, Mullana, Kalpana Chawla Government HospitalKarnal and Civil Hospital Ambala.

Ethical approval to conduct study was obtained from institutional ethical committee of M.M. University, Mullana. Consent form was prepared in Hindi and the consent was taken from the parents regarding their willingness to participate in the research project. The purpose for carrying out research project was explained to the subjects and assurance of confidentiality was given.

\section{Data collection procedure}

Data collection was done from 27.12.2014 to 10.03.2015.Structured Knowledge Interview Schedule was used to collect the data from parents of children with nephrotic syndrome. Rapport was developed with parents. Purpose of the study was explained to parents, the confidentiality of their response was assured and written consent was taken prior to the study.

The average time taken by parents to complete structured knowledge questionnaire was 20-25 $\mathrm{min}$ and $15-20 \mathrm{~min}$ for practices regarding home management of children with nephrotic syndrome. Inferential and descriptive analysis of data was done using SPSS version 20.0.

\section{Results and Discussion}

Findings of the study showed that majority of parents $(80 \%)$ were mother and $(20 \%)$ were father. Majority of parents $(43 \%)$ were in age group of 31-37, (30\%) were in age group of $24-30$ and (18\%) were in age group of 38-44. $(90 \%)$ were married and $(8 \%)$ were widow/widower. Maximum of parents were from Hindu (73\%) religion, (21\%) were Muslims. Maximum of the parents were non literate $(35 \%)$, (18\%) had higher secondary education, $(11 \%)$ had primary and secondary education. (68\%) were home maker and $10 \%$ were laborer and $(56 \%)$ had monthly income <5000, (18\%) had monthly income 500110000. (83\%) were residing to rural area and (16\%) were from urban area. Maximum of the parents not had family history of nephrotic syndrome, treatment modality adopted for the child was allopathic $(85 \%)$ and $(93 \%)$ parents were not had exposure of information regarding nephrotic syndrome. Out of sixty children majority of children were in age group of 4-6 year $(35 \%)$ and $(26 \%)$ were in the age group of 7-9 years. Majority of the children (93\%) were boys. Majority of the children had duration of illness1-6 month $(43 \%)$ and $(31 \%)$ were had $<1$ month of duration of illness. (50\%) of the children had the previous hospitalization and (50\%) were not had the previous hospitalization and (90\%) of children were not had the precipitating co-morbid conditions associated with the nephrotic syndrome.

The data in Table 1 shows that parents had below average knowledge i.e. $80 \%$ and $15 \%$ had average knowledge and $5 \%$ of the parents had good knowledge regarding home management of children with nephrotic syndrome.

The data presented in Table 2 depicts that mean knowledge score of parents was 11.13 and median was 11 with range of knowledge 
score was 9. It revealed that majority of parents had below average knowledge regarding home management of children with nephrotic syndrome.

The data presented in Table 3 showed the mean $\%$ of knowledge scores of parents. The highest mean \% score was found in skin care (79.17\%), sign and symptoms $(57.50 \%)$ and the lowest mean \% score was found in medication (7.50\%), urine examination $(10.56 \%)$.

This indicates that maximum knowledge score deficit existed in medication, urine examination, infection and complications, diet, concept and weight.

The data presented in Table 4 reveals that 93.3\% of parents had poor practices and $6.7 \%$ had fair practices regarding home management of children with nephrotic syndrome.

The data presented in Table 5 represents that mean percentage for practice score was 26.22 and standard deviation was found 8.40.

The data presented in the Table 6 depicts the lowest mean $\%$ scores of practices of parents was found in weight $(10.37 \%)$, urine examination $(12.91 \%)$, followed by dietary modification $(26.08 \%)$ and highest mean \% of practices of parents was found in daily living activities (55.3\%), emotional support (52\%) followed by preventions from infections and complications $(46.7 \%)$ respectively. This indicates that maximum practices of the parents was deficit in weight, urine examination, dietary modification and least practices of the parents deficit was in medication followed by skin care.

Table.1 Frequency and percentage distribution of knowledge scores of parents regarding home management of children with nephrotic syndrome

\begin{tabular}{lccc}
\hline $\begin{array}{l}\text { Level of } \\
\text { knowledge }\end{array}$ & Range & $\begin{array}{c}\text { Frequency } \\
\text { Score }\end{array}$ & $\begin{array}{c}\text { Percentage } \\
(\%)\end{array}$ \\
\hline Very Good & $23-30$ & 0 & 0 \\
Good & $19-22$ & 3 & 5 \\
Average & $15-18$ & 9 & 15 \\
Below & $0-14$ & 48 & 80 \\
Average & & & \\
\hline Max. Score $=30$ & & & Min. Score $=00$
\end{tabular}

Table.2 Range, mean, median and standard deviation of knowledge score of parents regarding home management of children with nephrotic syndrome

\begin{tabular}{ccccc}
\hline Variable & Range & Mean & Median & S.D \\
\hline $\begin{array}{c}\text { Knowledge } \\
\text { score }\end{array}$ & 9 & 11.13 & 11 & 4.180 \\
\hline Maximum score: 30 & & \multicolumn{2}{c}{ Minimum score: 00}
\end{tabular}


Table.3 Area wise mean, mean percentage, standard deviation of knowledge score of parents regarding home management of children with nephrotic syndrome

\begin{tabular}{clcccc}
\hline Sr. & Area & Max. & Mean & Mean\% & SD \\
No. & & Score & & & \\
\hline 1. & Concept & 2 & 0.70 & 35.00 & 0.462 \\
2. & Sign and & 2 & 1.15 & 57.50 & 0.444 \\
& symptoms & & & & \\
3. & Skin care & 4 & 3.17 & 79.17 & 1.028 \\
4. & Diet & 6 & 1.87 & 31.11 & 1.443 \\
5. & Weight & 3 & 1.20 & 40.00 & 0.659 \\
6. & Urine & 3 & 0.32 & 10.56 & 0.651 \\
& examination & & & & \\
7 & Medication & 2 & 0.15 & 7.50 & 0.360 \\
8. & Infection and & 6 & 1.72 & 28.61 & 0.922 \\
& complications & & & & \\
9. & Follow up & 2 & 0.87 & 43.33 & 0.623 \\
\hline Maximum score =30 & & & Minimum score $=00$
\end{tabular}

Table.4 Frequency and percentage distribution of practices of parents regarding home management of children with nephrotic syndrome

\begin{tabular}{lccc}
\hline $\begin{array}{l}\text { Level of } \\
\text { Practices }\end{array}$ & Range & $\begin{array}{c}\text { Frequency } \\
(\mathbf{f})\end{array}$ & $\begin{array}{c}\mathrm{Nercentage} \\
(\%)\end{array}$ \\
Scores & & & \\
\hline Good & $61-80$ & - & - \\
Fair & $41-60$ & 4 & 6.7 \\
Poor & $0-40$ & 56 & 93.3 \\
\hline
\end{tabular}

Maximum score $=80$

Minimum score $=00$

Table.5 Range, mean, median and standard deviation of practices score of parents regarding home management of children with nephrotic syndrome

\begin{tabular}{lcccc}
\hline Variable & Range & Mean & Median & S.D \\
& & & & \\
\hline $\begin{array}{l}\text { Practices } \\
\text { score }\end{array}$ & 42 & 26.22 & 27 & 8.40 \\
\hline Maximum score $=80$ & & \multicolumn{2}{c}{ Minimum score $=00$}
\end{tabular}


Table.6 Area wise mean, mean percentage standard deviation of practices score of parents regarding home management of children with nephrotic syndrome

\begin{tabular}{clcccc}
$\begin{array}{c}\text { Sr. } \\
\text { No. }\end{array}$ & Area & $\begin{array}{c}\text { Max. } \\
\text { Score }\end{array}$ & Mean & Mean\% & SD \\
\hline 1. & Weight & 8 & 0.83 & 10.37 & 1.291 \\
2. & $\begin{array}{l}\text { Urine } \\
\text { examination }\end{array}$ & 12 & 1.55 & 12.91 & 1.863 \\
3. & $\begin{array}{l}\text { Dietry } \\
\text { modification }\end{array}$ & 12 & 3.13 & 26.08 & 1.741 \\
4. & $\begin{array}{l}\text { Medication } \\
\text { 5. }\end{array}$ & 12 & 4.55 & 37.91 & 1.610 \\
6. & $\begin{array}{l}\text { Preventions } \\
\text { from }\end{array}$ & 14 & 5.05 & 36.07 & 2.746 \\
& 10 & 4.67 & 46.7 & 2.137 \\
& $\begin{array}{l}\text { infection and } \\
\text { complications }\end{array}$ & & & & \\
7 & $\begin{array}{l}\text { Daily living } \\
\text { activities }\end{array}$ & 6 & 3.32 & 55.3 & 1.321 \\
8. & $\begin{array}{l}\text { Emotional } \\
\text { support }\end{array}$ & 6 & 3.12 & 52 & 1.367 \\
\hline & & & & \\
\hline Maximum score $=80$ & & & Minimum score $=00$
\end{tabular}

Table.7 Co- relation between knowledge score and practice score of parents regarding home management of children with nephrotic syndrome

\begin{tabular}{lccc}
\hline & Mean & SD & r $=60$ \\
\hline Knowledge Score & 11.13 & 4.180 & $0.51^{*}$ \\
Practice Score & 26.22 & 8.403 & \\
\hline $\mathrm{r}(58)=0.254,{ }^{*}$ Significant $(\mathrm{p} \leq 0.05)$ & &
\end{tabular}

Findings in the Table 7 predicted the positive co-relation of knowledge score and practice score of parents $(0.51)$. The computed ' $r$ ' value between knowledge scores and practices scores obtained by parents was significant at 0.05 level of significance.

Association of knowledge score and practice score with selected variables

ANOVA computed between knowledge score and selected variables of parents i.e. occupation status of mother / father $(\mathrm{F}=3.077, \mathrm{p}=0.016)$, monthly income of family $(\mathrm{F}=2.581, \mathrm{p}=0.047)$, exposure of information $(\mathrm{F}=3.482, \mathrm{p}=0.001)$ which were found statistically significant at 0.05 level of significance, whereas ANOVA computed between knowledge score and selected variables of child were not found statistically significant at 0.05 level of significance.

ANOVA computed between practices score and selected variables of parents i.e. occupation status of mother / father $(\mathrm{F}=3.136, \quad \mathrm{p}=0.015), \quad$ exposure of information $(\mathrm{F}=4.661, \mathrm{p}=0.001)$ which were found statistically significant at 0.05 level of 
significance, whereas ANOVA computed between practices score and selected variables of child were not found statistically significant at 0.05 level of significance. The result of the present study revealed that majority of the parents $(80 \%)$ had below average knowledge regarding home management of children with nephrotic syndrome. The finding of the study was similar to the Ehsan Valavi (2013) which showed that parents $(18.2 \%)$ had not the good knowledge regarding nephrotic syndrome. The present study revealed there was a significant association between knowledge score and $(\mathrm{F}=3.077$; $\mathrm{p}=$ $0.001)$, monthly income of family ( $\mathrm{F}=2.581$; $\mathrm{p}=0.001)$, exposure of information $(\mathrm{F}=3.428 ; \mathrm{p}=0.001)$ were found to be significant at 0.05 level of significance. The opposite findings of study conducted by Ehsan Valavi showed that there was not a significant correlation between education of mothers with knowledge scores (0.6).

The present study revealed that majority of the parents $(93.3 \%)$ had poor practices regarding home management of children with nephrotic syndrome. The same findings by Feryal A. Zyarah et al., (2011) study showed that mothers had poor practices (61.3\%) regarding nephrotic syndrome. The present study practices scores with occupational status of parents $(\mathrm{F}=3.136 ; \mathrm{p}=$ $0.001)$, exposure of information $(\mathrm{F}=4.66 ; \mathrm{p}=$ 0.001 ) were found to be significant at 0.05 level of significance. The opposite findings of study conducted by Feryal A. Zyarah $e t$ al., (2011) showed that there was a significant association between mothers' practices and their educational level, and duration of the child's disease. The present findings of the study revealed that majority of the parents had never give food to child without salt $(85 \%)$. Majority of the parents did not interrupt the drug therapy of child without doctors order $(60 \%)$. The more than half $(56.3 \%)$ of mothers sometimes avoid adding salt to the child's food. The majority of parents $(88.3 \%)$ had never done urine exam at home. Majority of the parents had never weigh $(66.7 \%)$ the child daily. The same findings by Zyarah et al., (2011) showed that half of mothers (51.3\%) did not interrupt therapy without doctor advice. The majority of mothers (91.3\%) had never done urine exam at home. In regard to weighing the child, $(87.5 \%)$ of mothers had never done. $(45.0 \%)$ mothers observed the urine amount sometimes while $(53.8 \%)$ sometimes does. More than third (42.5\%) of mothers did not interrupt therapy without doctor order, $(40.0 \%)$ of mothers sometimes observed increase in urine excretion.

In conclusion, majority of the parents had below average knowledge and poor practices regarding home management of children with nephrotic syndrome. Significant positive co-relation was found between knowledge scores and practices scores of parents regarding home management of children with nephrotic syndrome. Significant association found between knowledge score with occupational status of parents $(\mathrm{F}=3.077 ; \mathrm{p}=0.001)$, monthly income of family $(\mathrm{F}=2.581 ; \mathrm{p}=$ $0.001)$, exposure of information $(\mathrm{F}=3.428$; $\mathrm{p}=0.001)$. Significant association found between practices score with occupational status of parents $(\mathrm{F}=3.136 ; \mathrm{p}=0.001)$, exposure of information $(\mathrm{F}=4.66 ; \mathrm{p}=0.001)$ at 0.05 level of significance.

\section{References}

1. Ghai OP, Piyush Gupta, Paul VK. Ghai Essential Pediatrics. 8th ed. New Delhi: CBS Publishers and distributors; 2013:552-560

2. Marlow R. Dorothy, Redding A. Barabara. Textbook of Paediatric 
Nursing.6th Edition. Elsevier India pvt.ltd.2010;9:957-966

3. Roberto Gordillo and Adrian Spitzer. The Nephrotic Syndrome. Pediatrics in Review. 2009;30(2):94-104

4. http://www.kidney.org/atoz/content/child ns.cfm/11

5. Ashrafalsadat et.al. A study about knowledge of parents of children with nephrotic syndrome toward recurrence of disease. Jundishapur Journal of Chronic Disease Care. 2013;2(4):49-55

6. Feryal A et.al. Assessment of mothers' practices toward children with steroid sensitive nephrotic syndrome at pediatrics hospitals in Baghdad city. Iraqi National Journal of Nursing Specialties.2011; 24( 2):13-25.

\section{How to cite this article:}

Sarika. 2017. Assessment of Knowledge and Practices of Parents Regarding Home Management of Children with Nephrotic Syndrome at Selected Hospitals of Haryana, India. Int.J.Curr.Microbiol.App.Sci. 6(10): 1496-1503. doi: https://doi.org/10.20546/ijcmas.2017.610.178 